NBER WORKING PAPER SERIES

\title{
THE EXTERNAL IMPACT OF CHINA'S EXCHANGE RATE POLICY: EVIDENCE FROM FIRM LEVEL DATA
}

\author{
Barry Eichengreen \\ Hui Tong \\ Working Paper 17593 \\ http://www.nber.org/papers/w17593 \\ NATIONAL BUREAU OF ECONOMIC RESEARCH \\ 1050 Massachusetts Avenue \\ Cambridge, MA 02138 \\ November 2011
}

We thank Rudolfs Bems, Olivier Blanchard, Nigel Chalk, Roberto Chang, Stijn Claessens, Charles Engel, Robert Feenstra, Kristin Forbes, Jeffery Frankel, Marcel Fratzscher, Takatoshi Ito, Andrei Levchenko, Raul Razo-Garcia, Shang-Jin Wei, and seminar participants at the IMF, the ECB, the 2011 Econometrics Society Winter Meeting, and the NBER IFM 2011 Spring Meeting for helpful comments and Mohsan Bilal for excellent research assistance. The views in the paper are those of the authors and do not necessarily reflect those of the IMF or the National Bureau of Economic Research. This Paper was also published as IMF Working Paper 11/155, and has been reproduced with permission.

NBER working papers are circulated for discussion and comment purposes. They have not been peerreviewed or been subject to the review by the NBER Board of Directors that accompanies official NBER publications.

(C) 2011 by Barry Eichengreen and Hui Tong. All rights reserved. Short sections of text, not to exceed two paragraphs, may be quoted without explicit permission provided that full credit, including $\odot$ notice, is given to the source. 
The External Impact of China's Exchange Rate Policy: Evidence from Firm Level Data

Barry Eichengreen and Hui Tong

NBER Working Paper No. 17593

November 2011

JEL No. F0,F3,F30,F31

\begin{abstract}
$\underline{\text { ABSTRACT }}$
We examine the impact of renminbi revaluation on firm valuations, considering two surprise announcements of changes in China's exchange rate policy in 2005 and 2010 and data on 6,050 firms in 44 countries. Renminbi appreciation has a positive effect on firms exporting to China but little positive or even a negative impact on those providing inputs for China's processing exports. Stock prices rise for firms competing with China in their home market while falling for firms importing Chinese products with large imported-input content. Renminbi appreciation also reduces the valuation of financially-constrained firms, particularly in more financially integrated countries.
\end{abstract}

Barry Eichengreen

Department of Economics

University of California, Berkeley

549 Evans Hall 3880

Berkeley, CA 94720-3880

and NBER

eichengr@econ.Berkeley.edu

Hui Tong

Research Department

IMF Washington DC

700 19th Street N.W.

Washington, DC 20431

htong@imf.org 


\section{Introduction}

The effects of China's exchange rate are a prominent topic in both policy debate and analytical discussion. In policy circles, the questions include whether China should allow its currency to appreciate to encourage global rebalancing - that is, to shift the composition of activity away from exports and facilitate the efforts of deficit countries like the United States to export more. ${ }^{1}$ They include whether a change in Chinese currency policy would have a significant impact on U.S. output and employment. ${ }^{2}$

In analytical discussions, the questions include how a change in Chinese exchange rate policy would affect different sectors and activities in other countries. China exports a wide range of final goods. Foreign firms competing with Chinese exporters of these products should therefore feel positive effects from a change in policy that signals greater Chinese willingness to allow the renminbi to rise. Similarly, China is increasingly important as a source of parts and components for manufacturing in other countries. Firms relying on these inputs will therefore be adversely affected by renminbi appreciation that makes those inputs more expensive. Some investigators focusing on the United States conclude that this channel has grown to the point where the impact of renminbi appreciation on U.S. firms would be negative on balance. ${ }^{3}$

Foreign producers exporting final goods to China, for their part, would benefit from renminbi appreciation that increases the purchasing power of Chinese firms and households. Insofar as currency appreciation is accompanied by other measures designed to stimulate domestic spending, the benefit to countries exporting final goods to China would be greater still.

\footnotetext{
${ }^{1}$ For competing perspectives, see Eichengreen (2007), Dooley et al. (2009), Hanson and Robertson (2010), and Blanchard and Milesi-Ferretti (2011).

${ }^{2}$ For competing perspectives see Scott (2010) and Evenett and Francois (2010).

${ }^{3}$ As documented in the U.S. case by Evenett and Francois (2010) and, in more detail, by Francois (2010).
} 
China is also a source of demand for parts and components produced in Asia and elsewhere. ${ }^{4}$

While renminbi appreciation would increase China's command over these products, it could also signal a shift away from the export-oriented assembly operations that have been a source of this demand. $^{5}$

Finally, China is an important purchaser of foreign assets and influence on foreign financial conditions. Its purchases of U.S. treasury securities are a concomitant of its exchange rate regime; they are required to prevent the renminbi from rising more rapidly against the dollar. Greater willingness to allow the renminbi to rise might imply fewer Chinese purchases and, in turn, higher foreign yields (e.g. Bernanke 2005, Bernanke et al 2011). This could affect the cost of funding for foreign corporations insofar as that cost is linked to conditions in treasury markets. Foreign firms depending most on external finance would presumably be hit hardest.

These effects could then be tempered or reinforced by the foreign response to changes in China's currency policy. Indications that China is prepared to allow its currency to appreciate would reduce the risk of trade sanctions by countries that have strongly advocated renminbi revaluation, positively affecting foreign firms that benefit from trade with the country. The currencies of other emerging markets might appreciate along with the renminbi, something that would have further implications for foreign firms and their competitors. ${ }^{6}$

\footnotetext{
${ }^{4}$ Based on Chinese trade statistics, 45.7 per cent of China's imports in 2006 were used for so-called processing exports (35.7 per cent being intermediate inputs and 10 per cent being capital-goods imports).

${ }^{5}$ Garcia-Herrero and Koivu (2009) estimate that a ten per cent rise in the renminbi would reduce China's imports of components by as much as 6 per cent. Ahmed (2009) also find that renminbi appreciation could cause both China's processing and non-processing exports to go down, by examining the latest data till 2009. His finding reinforces the conclusions of some earlier studies, such as Marquez and Schindler (2006), which found that Chinese exports respond strongly to movements in the real exchange rate.

${ }^{6}$ It is worth mentioning that we focus on the exchange rate angle. As the currency may be only one part of the global rebalancing, our exercise is therefore narrowly defined and examining just one piece of the global rebalancing.
} 
In this paper we test for the importance of these channels through which a change in Chinese exchange rate policy can impact firms in other countries. We ask how announcements by the People’s Bank of China (PBOC) on July 21 $1^{\text {st }}, 2005$ and June $19^{\text {th }}$, 2010, both of which created expectations of currency appreciation, affected the market valuation of foreign firms. These two events were driven more by political factors than concurrent macroeconomic news in China, with the timing and extent being a surprise to the market. ${ }^{7}$ This provides us with a way of dealing with the endogeneity problem that plagues studies of the impact of exchange-rate announcements on financial variables.

Since we have only two PBOC announcements, we also consider a set of politicallydriven changes in prospective Chinese exchange rate policy as perceived by the markets. We identify large movements in renminbi non-deliverable forward contracts and use media coverage to distinguish movements driven by political factors rather than macroeconomic news. Using this approach we identify four instances where there were expectations of politically-driven changes in China’s exchange rate.

By focusing on these politically-driven events, we aim to address a basic challenge in the empirical literature on exchange rates, i.e., the difficulty of separating the impact of exchange rate changes on other macroeconomic variables from causality running in the opposite direction. As Engel (2009) writes of the exchange-rate-trade-balance nexus, “...it is very difficult to assess the effect of exchange rates on trade balances. There are few if any cases of "exogenous" changes in the exchange rate...Instead, any comovements between exchange rates and trade quantities are confounded by the forces that cause the exchange rate to change in the first

\footnotetext{
${ }^{7}$ At the time of both announcements, there was little indication of inflation accelerating to unacceptably high levels or of irrational exuberance in asset markets. In the second case, Chinese inflation did eventually accelerate, but considerably later (in early 2011).
} 
place...But then it is hard econometrically to separate out the effect of the depreciation on the trade balance and the effect of the trade balance on the depreciation." ${ }^{8}$ To the extent that the PBOC announcements and NDF movements we consider reflect political rather than economic factors, this problem of reverse causality will not be as serious as in other contexts.

Firm-level data permit us to distinguish different channels through which Chinese currency policy affects other countries. We can distinguish firms that compete with Chinese exports of similar products from firms that export directly to China. We can distinguish exporters of parts and components from exporters of final goods. We can distinguish foreign firms according to their degree of dependence on external finance.

We find that the stock returns of non-Chinese corporations rise in response to expectations of renminbi appreciation. This response appears to be associated with general market sentiment, which we interpret in terms of reduced risk of trade-policy conflict, as well as with specific trade effects. There are, at the same time, pronounced differences across firms. A large positive effect is evident for exporters of final goods to China. Suppliers of inputs for China's processing exports, in contrast, experience no significant net market-valuation effects at the time of the two PBOC announcements. ${ }^{9}$

We find similar patterns when examining the implications of Chinese currency policy for competition in the firm's home markets. Firms competing with China in home markets in selling

\footnotetext{
${ }^{8}$ Earlier studies have examined how exchange rates affect equity prices (see for example Phylaktis and Ravazzolo 2005). Effects for individual firms vary in the expected way according to exposure to exchange rates (firm size, multinational status, foreign sales, international assets, competitiveness and so forth; see Bartov and Bodnar (1994), He and Ng (1998), Griffin and Stulz (2001), Williamson (2001), Bodnar, Dumas and Marston (2002), Dominguez and Tesar (2006), Parsley and Popper (2006), and Bartram, Brown, and Minton (2010) ).

${ }^{9}$ Possibly, the positive income effect of renminbi appreciation is offset by the negative effect from reduced derived demand for processing inputs. Other recent work also finds a negative long-term impact of renminbi appreciation on China's imports, plausibly reflecting this imported-input effect. For example Marquez and Schindler (2006), and Cheung, Chinn and Fujii (2010), using aggregate country-level data, find that Chinese ordinary imports rise in response to renminbi depreciation.
} 
final products face less competition from China after renminbi appreciation; their share prices benefit correspondingly. In contrast, there is little evidence of analogous benefits for firms competing in their home market with China in processing trade. Firms competing with China in third markets also face less competition, and their share prices rise accordingly. Finally, there is some support for the view that announcements of changes in Chinese currency policy, by causing investors to revise upward their estimates of actual and expected treasury yields, reduce the market valuation of firms that depend on external finance for funding their investment.

These patterns are still evident when we control for firm-specific characteristics and sector, year and country fixed effects. They carry over when we control for local currency movements at the time of renminbi appreciation. They hold whether total stock returns or abnormal returns are used as the dependent variable. Placebo tests for similar effects on adjoining days do not find them, suggesting that these effects are not being caused by other events affecting market valuations. Finally, most these patterns continue to hold when we expand our sample to four dates of market expectations of politically-motivated changes in renminbi policy.

We describe our data and methodology in Section II. Section III presents results for the two PBOC announcements. Section IV reports robustness checks, while Section V extends the sample to four dates when there were market expectations of politically-motivated changes in Chinese exchange rate policy. Section VI then concludes. 


\section{Data and Methodology}

Our basic specification is of the form:

StockReturn $_{i j k t}=\beta$ TradeChannels $_{j k t}+\gamma$ FinancialChannel $_{j k t}+\lambda$ Controls $_{i j k t}+\varepsilon_{i j k t}$

Here "Stock Return" is the one-day return for firm i in sector j in country k at time t. "Trade Channel" encompasses three trade-related effects of China's exchange rate announcements: the impact on exports to China, the impact on imports from China, and the impact on competition with China in third markets. Trade data are collected from the UN Comtrade data set, which provides information on bilateral imports and exports for each country pair at the 4-digit US SIC level.

The problem of reverse causality running from stock prices to exchange rate policy should not be as serious here as in other studies of the relationship between exchange rates and related variables, since our stock price variable is highly disaggregated while the exchange rate is a macroeconomic variable. That is to say, movements in individual share prices are unlikely to affect an economy-wide aggregate like the exchange rate. Nonetheless, to further address the possibility of reverse causality, we lag the trade data, using 2004 observations for the 2005 announcement and 2008 observations for the 2010 announcement. ${ }^{10}$ We also focus on episodes where expectations of changes in the exchange rate arise from political as opposed to economic developments, as explained below.

In practice we distinguish the importance for these various classes of firms of (a) China's own market, as captured by exports to China by sector j of country k divided by global exports of

\footnotetext{
${ }^{10} 2009$ data would be contaminated by the effects of the financial crisis.
} 
sector $\mathrm{j}$ of country $\mathrm{k}$, (b) the impact on home-market competition, as captured by imports from China by sector $\mathrm{j}$ in country $\mathrm{k}$ divided by total imports of sector $\mathrm{j}$ in country $\mathrm{k}$, and (c) Chinese competition in third markets. ${ }^{11}$ We construct the third-market competition index as follows: i) For a third-market in a given year, say the U.S. in 2004, we first calculate its importance to an exporter, say the steel industry in Korea, as Korean steel exports to the U.S. divided by Korean aggregate steel exports; ii) We then calculate the share of China's steel products in the U.S. steel market, measured as China's steel exports to the U.S. divided by total U.S. steel imports; iii) We multiply the US importance to the Korean exporter (from i) and the share of China's product in the U.S. (from ii), and sum the result over all importing countries (across the U.S., Euro area, Japan, etc...) to derive the third-market competition index faced by Korean steel industry. Hence the trade channel in equation (1) now becomes:

$\beta$ (Trade Channels ${ }_{j k t}$ )

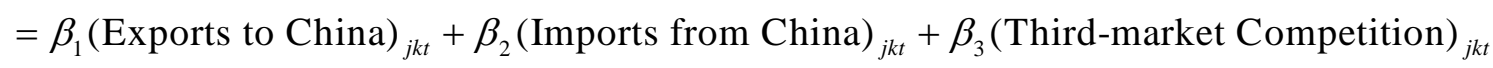

All measures of trade channels vary across country, sector and year and hence still allow us to include fixed effects for countries, sectors and years.

We compute stock returns as follows. For the July 21 $1^{\text {st }}, 2005$ announcement (Thursday, $4 \mathrm{pm}$ Shanghai time), we take the log change in the closing price between July $21^{\text {th }}$ and July $22^{\text {nd }}$ for Asian firms. For firms in other countries we take the log difference in the closing price between July $20^{\text {th }}$ and July $21^{\text {st }}$ so as to control for time-zone effects. For the June $19^{\text {th }}, 2010$

\footnotetext{
${ }^{11}$ The second and third of these variables are constructed following Forbes (2004). For sectors with no export data, these trade channels are assigned a value of zero.
} 
announcement, which occurred on a Saturday, we take the log difference between closing prices on June $18^{\text {th }}$ and $21^{\text {st }}$. Stock prices are from Datastream. ${ }^{12}$

Table I shows the number of listed manufacturing firms by country. We consider all countries other than China for which data on at least four firms are available (44 economies in all).

Table II shows market returns and exchange rate movements around these two announcements. Three fourths of our sample countries experienced a rise in stock prices with an average stock market return of $0.6 \%$ and a standard deviation of $1.1 \%$. Interestingly, the U.S. stock market return is negative around the time of both announcements (- $0.69 \%$ in 2005 , and 0.39\% in 2010). Whether these heterogeneous responses are due to idiosyncratic shocks or systematic factors is to be determined.

Some currencies, particularly in Asia, appreciated together with the renminbi around the time of the two announcements (again see Table II). This suggests another channel through which renminbi announcements can affect foreign stock markets: by affecting other exchange rates. $^{13}$

Figure 1 juxtaposes stock market returns and trade with China for different countries. The top two charts consider exports to China over total exports around the time of the two PBOC announcements. It is hard to detect a significant association between the stock market reaction and total exports to China. The bottom two charts consider imports from China over total imports, again for the two PBOC announcements. Again it is hard to discern a simple correlation. ${ }^{14}$

\footnotetext{
${ }^{12}$ In robustness checks, we will also study abnormal stock market returns (see below).

${ }^{13}$ We will consider this as well in the analysis.

${ }^{14}$ The association between the stock market reaction and import exposure to China was actually negative in 2005.
} 
However, the absence of a correlation could result from the presence of different factors working in opposite directions and affecting different firms differentially. While foreign firms exporting final products to China should benefit from the additional demand that comes with appreciation, foreign firms exporting components to China for processing trade could suffer due to the decline in demand for China's final exports. Similarly, firms relying Chinese products as inputs into their own production, including the parent companies of Chinese subsidiaries and other upstream companies that are part of the same global supply chain, may find their costs increased by renminbi appreciation.

To control for these factors we extend the analysis of trade effects as follows:

$$
\begin{aligned}
\beta \text { Trade Channels }_{j k t}= & \left(\beta_{11}+\beta_{12} \text { China's Processing Imports }_{j}\right) *\left(\text { Exports to China }_{j k t}\right) \\
& +\left(\beta_{21}+\beta_{22} \text { China's Processing Exports }_{j}\right) *\left(\text { Imports from China }_{j k k}\right) \\
& +\left(\beta_{31}+\beta_{32} \text { China's Processing Exports }_{j}\right) *\left(\text { Third-market Competition }_{j k t}\right)
\end{aligned}
$$

where we expect that $\beta_{12}<0$. That is, firms supplying inputs to China for that country's processing trade will experience stock-price declines. We similarly expect $\beta_{22}<0$, since firms importing inputs from China will experience higher costs as well. ${ }^{15}$

Data for China’s processing trade are from Koopman, Wang and Wei (2008), who use the UN BEC classification and processing-trade information from China Customs Trade Statistics to identify the use for imports of some 100 sectors in China for the year of 2002. ${ }^{16}$ The authors

\footnotetext{
${ }^{15}$ A large literature considers the location and magnitude of processing trade (e.g., Feenstra and Hanson (2005)). In this paper we focus not on questions of location and magnitude but on how the exchange rate shock affects firm valuation given the pattern of processing trade.

${ }^{16}$ China's Customs Trade Statistics classifies imports to China as for processing trade or for normal usage. Koopman et al. (2008) report the classifications for two years of 1997 and 2002. We use the later as it is closer to our events of PBOC announcements. See also Koopman et al. (2010) for more details.
} 
estimate the shares of intermediates for processing exports, intermediates for normal use, capital goods for normal use, capital goods for processing exports, and final consumption goods. To calculate China's Processing Imports ${ }_{j}$ for sector $j$, we sum over the share of intermediates for processing exports and the share of capital goods for processing exports. The resulting variable ranges from 0.02 to 0.85 , with a mean of 0.43 and a median of $0.48 .{ }^{17}$ Koopman, Wang and Wei (2008) use China’s 2002 input-output table to calculate the percentage of direct foreign valueadded in China's exports, by industry. Following their example, we use this percentage as a proxy for the comparable variable on the export side, China's Processing Exports ${ }_{j}$. This ranges from 0 to 0.99 , with a mean of 0.37 and a median of $0.40 .^{18}$

The variable "Financial Channel" is designed to capture the impact of renminbi appreciation expectations on corporate funding costs, for firms that depend on external finance in particular, insofar as renminbi appreciation is expected to imply reduced Chinese purchases of U.S. treasury securities and put upward pressure on yields generally. We construct a sector-level approximation of a firm’s intrinsic dependence on external finance for capital investment following the methodology of Rajan and Zingales (1998):

Dependence on external finance for investment $=\frac{\text { capital expenditures }- \text { cash flow }}{\text { capital expenditures }}$

\footnotetext{
${ }^{17}$ Sectors with large share of imports for processing exports include, for example electronic element and device, and plastic products, while sectors with small share of imports for processing exports include chemical fertilizers and medical products.

${ }^{18}$ The sectors identified with large processing exports include for example electronic and communication equipment and household electric appliances, while sectors with small processing exports include chemical pesticides and cement, lime and plaster.
} 
where "cash flow" denotes cash flow from operations plus reductions in inventories plus decreases in receivables plus increases in payables. Conceptually, the Rajan-Zingales (RZ) index aims to identify sectors that are naturally more dependent on external financing for their investment and other business operations. ${ }^{19}$

Following standard practice, the RZ index is calculated using data for U.S. firms, which are assumed to suffer least from financing constraints of a sort likely to disguise their underlying reliance on external finance. While the original Rajan and Zingales (1998) paper covers 40 (mainly SIC 2-digit) sectors, we expand the coverage to 90 SIC 3-digit sectors. To calculate the dependence external financing of U.S. firms, we first sort all firms listed in COMPUSTAT USA into SIC 3-digit sectors. We then calculate the external-finance-dependence ratio (eqn. 4) for each firm on average for the period 1990-2006. Finally we take the sector-level median from firm ratios for each SIC 3-digit sector with at least 5 firms as the index of demand for external finance by firms in that sector. To capture the percentage of capital expenditure financed externally, we winsorize our version of the RZ index to range from 0 to 1 , as in Tong and Wei (2011).

We also add as control variables firm size (log assets in US dollars), and country, date and sector fixed effects.

Table III provides summary statistics for the dependent variables and explanatory variables. Throughout we cluster standard errors by sector.

\footnotetext{
${ }^{19}$ In so doing it ignores the question of which firms within a sector are more liquidity constrained. What the RZ index measures could be regarded as a technical or technological characteristic of the sector, almost like a part of the production function.
} 


\section{Results for the Two PBOC Announcements}

In this section, we first report results for the trade channel (Tables IV to VI) and financial channel (Table VII) separately, before including them both in a single equation (Table VIII).

\section{A. Exports to China}

Table IV presents benchmark estimates for firms exporting to China. The first column shows that, on average, such firms are expected to benefit from RMB appreciation. The coefficient in question is significantly different from zero at the 10 percent confidence level.

In addition, however, the constant term is positive and significant at the 1 per cent confidence level. This raises the question of whether the observed increase in stock valuations is driven by trade-related effects or general market sentiment, where market sentiment might improve because expectations of renminbi appreciation reduce fears that the U.S. might brand China as a currency manipulator and impose trade sanctions to which China might retaliate. Public commentary is consistent with some role for this second factor. ${ }^{20}$

In Column 2 we therefore add (China's Processing Imports $\left._{j}\right) *\left(\right.$ Exports to China $_{j k t}$ ), as in equation (3), including also its components as controls. Exports to China has a significant positive coefficient, confirming that firms selling final products to China are expected to benefit from renminbi appreciation. The interaction term is negative, and its coefficient differs

\footnotetext{
${ }^{20}$ BBC Business (6/21/2010) noted in the wake of the 2010 announcement that Chinese yuan flexibility comments buoyed markets, as "the move, ahead of the G20 summit later this month, has tempered market fears of a possible trade war between China and the U.S.” Deutsche Bank Global Market Research (6/21/2010) noted that "the decline in the probability of a trade war between China and the US - as a result of China's currency move -- should help lift market sentiment for risky asset classes." AFP London (Jun 21, 2010) similarly noted that "Global equities surged on Monday after China said it would relax constraints on the yuan, in a surprise move seen by analysts as an attempt to defuse tensions before a crucial G20 summit this weekend ... Investor sentiment has improved quite dramatically over the weekend, with the news that China has pledged to allow its yuan to appreciate, helping to drive all major markets higher."
} 
significantly from zero at the 1 per cent confidence level. Plausibly, the positive impact otherwise felt by firms exporting to China is smaller for sectors where China imports products for use in the production of processing exports.

From the point estimates in Column 2, we see that the net effect for firms exporting to China in sectors with few processing inputs is large, while the net effect can be small and even negative for firms exporting to China in sectors with significant processing inputs. To illustrate, consider two firms, both with 20 per cent of their exports going to China. Suppose one firm is in the wine sector (where the data suggest that 1.8 per cent of exports to China are used as processing inputs ${ }^{21}$ ); its stock price would then increase by 0.51 per cent (we include the constant term of 0.25 per cent). This is a large effect compared with the average market return of 0.27 per cent estimated to occur in response to these two events. Suppose now that the other firm is from the electronic components sector (where 82 per cent of exports to China are used as processing inputs). This firm's stock return would rise by only 0.16 per cent. This makes the difference in stock returns between the two firms 0.35 percent $(0.51 \%-0.16 \%)$.

Other factors besides firms' exports to China may of course affect stock returns. We now add variables designed to help capture these factors, such as firm size (as measured by the log of book assets in US dollars), information on which is from Worldscope. ${ }^{22}$ Adding firm size in Column 3 actually slightly increases the magnitude of the interaction of China's Processing Imports and Exports to China, with the interaction term remaining significantly different from zero at the $1 \%$ level.

In Column 4 we add fixed effects for the announcement day, country, and 3-digit US SIC sector. While the magnitude of the negative effect on China's Processing Imports * Exports to

\footnotetext{
${ }^{21}$ One wonders: are the bottles being reused?

${ }^{22}$ An alternative is to focus on abnormal returns, as we do in subsequent sections.
} 
China declines slightly (logically insofar as part of its impact is now captured by fixed effects), it remains significant at the $5 \%$ level.

While the pattern of stock returns across firms is consistent with the global-productionchain story, we also consider alternative explanations, such as that countries exporting more to China experience faster appreciation of their own currencies. It is widely argued, for example, that neighboring Asian countries trading heavily with China are reluctant to see their currencies rise for fear of losing market share there or in their home markets, fears that should be attenuated if the renminbi is itself allowed to rise against extra-regional currencies.

To capture this possibility we add two interaction terms: Local Currency Appreciation * Exports to China, and RMB Appreciation*Exports to China. ${ }^{23}$ While the preceding logic suggests that local currency appreciation is likely to be endogenous with respect to renminbi appreciation, the level of the exchange rate is a country-level variable beyond the influence of individual firms. Hence it should still provide some insight into the question at hand.

In Column 5 of Table IV, RMB Appreciation*Exports to China has a significant positive coefficient, while Local Currency Appreciation*Exports to China has a significant negative one. Both signs accord with the preceding intuition. The interaction of China's Processing Imports and Exports to China still has a negative coefficient (-2.37) that is statistically significant at the 1\% level, consistent with earlier results. In Column 6, we add country, date and sector fixed effects. Local Currency Appreciation * Exports to China is no longer significant, while previous results continue to hold for the interaction of China's Processing Imports with Exports to China.

\footnotetext{
${ }^{23}$ In a sense we have already provided for this possibility by including country fixed effects and year fixed effects. But the two new variables should capture this possibility more directly.
} 
Allowing for the asymmetric response of local currencies thus leaves our interpretation in terms of global supply chains unaffected.

In Column 7, we add a dummy variable for whether a sector has an above-median value for China's Processing Imports (i.e, >=0.5) to help to control for measurement error in the index of China's Processing Imports. We interact this dummy with Exports to China. Again the coefficient on the interaction term is negative and significant at the $1 \%$ level.

In Column 8, we consider focus on electronic components as a case study of processing trade. Electronic components are defined as U.S. SIC Industry Group 367 (Electronic Components and Accessories). Note that the export of laptops alone contributes to about half of China's surplus in processing trade. ${ }^{24}$ We therefore define a dummy variable to denote firms active in these sectors; this takes on a value of one for 7 per cent of the firms in the sample. Component sector * Exports to China enters with a negative coefficient in Column 8, consistent with the idea that firms exporting components to China are negatively affected by renminbi appreciation.

\section{B. Competition in home market}

In Table V we consider competition in the firm's home market as captured by imports from China as a share of total imports. Specifically, we ask how imports from China affect stock prices. In Column 1, the coefficient on this variable is positive and significant at the $10 \%$ level. It would appear that expectations of renminbi appreciation boost stock prices for firms that compete with China in their home markets. In Column 2 we ask whether the results vary with the degree of processing trade in imports from China, adding

2495 percent of laptops worldwide being assembled in China. See "Processing Industry at Root of Trade Imbalance,” China Daily (1/6/2011). 
$\left(\right.$ China's Processing Exports $\left.{ }_{j}\right) *\left(\right.$ Imports from China $\left._{j k t}\right)$. The hypothesis is that firms importing Chinese products that themselves possess high imported-input content are likely to feel negative effects insofar as they are parent companies of Chinese subsidiaries or reside upstream of China in the relevant production chain. The index of China's Processing Exports is from Koopman et al (2008), which uses China’s input-output table to calculate the contribution of processing trade to final exports for 99 sectors.

The coefficient on (China's Processing Exports $\left.{ }_{j}\right) *\left(\right.$ Imports from China $_{j k t}$ ) is negative and significantly different from zero at the 5 per cent confidence level, indicating that expectations of renminbi appreciation depress stock returns for firms importing products from China with high processing content. In contrast, the coefficient on Imports from China is positive, suggesting that international firms competing with China in final-product trade are expected to face less competition in their home market. The point estimate for the interaction term is -1.59 , while the point estimate for Imports from China is 1.58. Given that the average ratio of China's Processing Exports is 0.38, this means that on average, sectors experience an increase in stock prices as a result of expectations operating through this home market channel.

In Column 3 we again control for firm size. The magnitude of the coefficient on (China's Processing Exports $\left.{ }_{j}\right) *\left(\right.$ Imports from China $_{j k t}$ ) increases slightly and remains significant at the 5 per cent confidence level. In Column 4, we add country, year and 3-digit sector dummies. Now the coefficient on the interaction term is somewhat reduced in magnitude and becomes insignificant at the traditional confidence level.

Column 5 controls for local currency appreciation. RMB appreciation * Imports from China has a significant positive coefficient, while Local Currency Appreciation * Imports from China has a negative coefficient, consistent with preceding intuition. Moreover, the interaction 
of Chinese Processing Exports with Imports from China now has a larger magnitude and is significant at the 10 per cent confidence level.

\section{Third-market competition}

Table VI focuses on third-market competition. The variable capturing this effect enters in Column 1 with a positive and significant coefficient, suggesting that firms competing with Chinese firms in third markets indeed benefit from renminbi appreciation.

In Column 2 we add the interaction of Third-market competition with China's processing exports. The new term is negative but insignificant. In Column 3, we include firm size, and sector, country, and year fixed effects. The interaction term becomes positive but remains insignificant.

Column 4 controls for local currency appreciation. RMB appreciation * Third market competition now enters with a significant positive coefficient, while Local currency appreciation * Third market competition has an insignificant coefficient, consistent with preceding intuition. Moreover, the coefficient on the interaction of Chinese processing exports with Third market competition is now smaller in magnitude and remains statistically insignificant.

\section{Financial channel}

In Table VII, we consider the possibility that expectations of renminbi appreciation put upward pressure on treasury yields, making it more expensive for financially-dependent firms to fund their operations. U.S. treasury yields in fact rose on both announcement dates, consistent with the idea that faster renminbi appreciation would mean fewer PBOC purchases of U.S. treasury bonds. 
The question is whether this had a differential impact on more financially dependent firms. As Column 1 shows, financially dependent firms saw their share prices decline with both two announcements of prospective changes in China's exchange rate regime, consistent with the hypothesis. The results carry through when we include firm-level control variables, i.e., firm size in Column 2, and when we further add country and year fixed effects in Column 3.

In Column 4, we add the interaction of financial dependence and financial openness (measured by the country's foreign assets and liabilities over GDP, following Lane and MilesiFerretti 2007). The hypothesis is that countries more integrated with global financial markets will be affected more by a rise in treasury yield. We find the interaction term indeed has a negative coefficient significant at the $1 \%$ level. The results for the financial channel remain the same if we add sector fixed effects, as in Column 5.

\section{E. Combining the trade and financial channels}

So far we have analyzed each transmission channel separately. In Table VIII we now combine the financial channel with three trade channels in a single specification. Dangers of multicolinearity notwithstanding, the previous results carry over. In Column 1, (China's processing imports)*(Exports to China) has a negative coefficient and is significant at the $5 \%$ level. Similarly, (China's processing exports)*(Imports from China) has a negative coefficient that is significantly different from zero at the 5 per cent confidence level. The coefficient on (China's processing exports)*(Third-market competition) remains positive, albeit insignificant. And (Dependence on external finance for investment)*(Financial openness) is still significantly negative at the 1 per cent confidence level. 
We add sector fixed effects in Column 2; again, the results carry over. Moreover, the coefficient on (China's processing exports)*(Third-market competition) is now significantly different from zero at the 5 per cent confidence level. Evidently, expectations of renminbi appreciation increase stock returns for firms competing with China in third markets in products with high processing content. The positive sign of the interaction term also suggests that our earlier finding of negative coefficient for (China's Processing Exports $\left.{ }_{j}\right) *\left(\right.$ Imports from China $_{j k t}$ ) is unlikely to be due to sector-specific features such as income sensitivity, since these features would generate same signs for (China's Processing Exports $\left.{ }_{j}\right) *\left(\right.$ Imports from China $_{j k t}$ ) and (China's Processing Exports $)_{j} *\left(\right.$ Third-Market Competition $\left._{j k k}\right) .{ }^{25}$

\section{Robustness Checks}

Abnormal returns have also been used to analyze the impact of macroeconomic shocks (by e.g, Mackinlay 1997). A common model of normal returns assumes a stable linear relation between the market return and individual security return:

$$
\text { Abnormal return }_{i, t}=\text { Stock return } n_{i, t}-\text { Alpha }_{i, t}-\text { Beta }_{i, t} * \text { Market return }_{k, t}
$$

We construct each firm's beta annually based on the correlation of weekly firm-level stock returns and local market returns. ${ }^{26}$ We then construct each firm’s alpha as the annual

\footnotetext{
${ }^{25}$ In other words, the opposite signs of (China's Processing Exports $\left.{ }_{j}\right) *\left(\right.$ Imports from China $_{j k k}$ ) and (China's Processing Exports $\left.{ }_{j}\right) *\left(\right.$ Third-Market Competition $_{j k k}$ ) are more consistent with the global production chain story.

${ }^{26}$ We use the domestic beta rather than a beta based on a world factor model because Griffin (2002) finds that domestic factor models perform better in explaining time-series variations in returns and have lower pricing errors than the world factor model.
} 
average of its weekly average return minus the beta multiplied by the annual average market return. We use the one-year-lagged beta and alpha in constructing the abnormal return around the two renminbi appreciation dates. ${ }^{27}$ We winsorize the dependent variable at the 1 per cent level to reduce the influence of outliers.

The results using abnormal returns are in Tables IX-X for exports to and imports from China. They confirm the findings of Tables IV and V. According to Column 1 of Table IX, firms exporting to China experience a decline in their abnormal stock returns around the time of the two renminbi appreciation announcements. While this result is not intuitive, it is consistent with the findings in Cheung, Chinn and Fujii (2010), where renminbi appreciation reduces China's imports. In Column 2 we include the interaction of Exports to China with China's Processing Imports. This term also has a negative coefficient that differs significantly from zero at the 5 per cent confidence level. However, the coefficient on Exports to China is no longer significant, suggesting that the negative coefficient in Column 1 is driven mainly by firms exporting processing inputs to China. In Column 3, where we add firm size and country, year and sector fixed effects, the interaction term increases somewhat in size and becomes significant at the 1 per cent confidence level. Column 4 controls for local currency appreciation. The coefficient on RMB appreciation * Exports to China is now insignificantly different from zero, while Local Currency appreciation * Exports to China has a significant negative coefficient, again consistent with preceding intuition. Reassuringly, the interaction of Exports to China with China's processing imports remains significant at the 1 per cent confidence level.

\footnotetext{
${ }^{27}$ As the alpha is constructed from weekly stock data, we use (1/5)*alpha in constructing the abnormal stock return from day $\mathrm{t}-1$ to $\mathrm{t}$.
} 
In Table $\mathrm{X}$ we consider imports from China in a specification like that in Table V but now using abnormal returns as the dependent variable. In Column 1 Imports from China enters negatively but does not differ significantly from zero. In Column 2 we include the interaction of Imports from China with China's Processing Exports. This interaction enters negatively, and its coefficient differs significantly from zero at the $1 \%$ confidence level. It remains significant at the 1\% level when we add firm size, country, year and sector fixed effects (Column 3). In Column 4, the interaction term remains significant when we control for local currency appreciation. Hence the analysis of abnormal stock returns confirms our earlier findings based on total returns.

In Table XI, column 1, we combine the trade channels (exports to China, home market competition and third-market competition) and financial channel in a single regression for abnormal returns. Column 2 then adds sector fixed effects. The results confirm our earlier findings for total returns: (China's processing imports)* (Exports to China) as significantly negative, (China's processing exports)*(Imports from China) as significantly negative, (China's processing exports)*(Third-market competition) as positive but insignificant, and (Dependence on external finance for investment*Financial openness) as significantly negative.

Finally, we analyzed daily stock returns on 7/19/2005 and 6/17/2010, i.e., two trading days before the PBOC announcements, as a placebo test. We do not find a significant coefficient for the trade channels. ${ }^{28}$ This reassures us that the stock-market response we detect is not reflecting other events occurring around the time of the two PBOC announcements.

\footnotetext{
${ }^{28}$ Results available from the authors on request.
} 


\section{Results for Market-Perceived Policy Changes}

While moving from country- to firm-level data extends the sample along one dimension the number of firms - it does little to expand it along the other - time - dimension, since as of the time of writing there have only two official announcements pointing to the prospect of future appreciation.

We address this problem by considering in addition to actual announcements changes in market expectations. We focus on large movements in the price of nondeliverable forward (NDF) dollar-renminbi contracts that coincide with newspaper articles about possible changes in Chinese exchange rate policy owing to foreign political pressure. We identify four dates in calendar year 2003 when movements in the renminbi NDF rate reacted strongly to political pressures, such as G-7 communiqués and speeches by senior U.S. officials. ${ }^{29}$ We use media coverage from Factiva to check that these NDF movements were not obviously responding to other macroeconomic news, such as new information on inflation, central bank policy rates or trade balances in China and the U.S.

Appendix Table 1 lists the four dates. Daily appreciation of the 12-month renminbi NDF rate on these four days ranges from 0.74 per cent to 1.16 per cent, with a mean of 0.90 per cent. ${ }^{30}$ In the case of the two PBOC announcements, by comparison, the daily change in the 12-month NDF is 0.37 per cent and 0.98 per cent. In terms of the magnitude of the exchange rate response, then, the two sets of episodes are broadly comparable.

In Column 1 of Table XII, we examine the impact of renminbi NDF appreciation in these four episodes on firm valuations, where we include firm size and country-date pair fixed

\footnotetext{
${ }^{29}$ There were also strong political pressures in year 2010 associated with talk of "currency wars”. But 2010 also saw a global financial crisis and many government interventions, which makes it more difficult to identify the effects of market-perceived RMB policy changes.

${ }^{30}$ In 2003 , there were five dates when the daily change of 12 month-NDF was larger than or equal to 0.7 per cent.
} 
effects. ${ }^{31}$ The coefficient on (China's processing imports)* (Exports to China) is negative and differs significantly from zero at the 5 per cent confidence level, consistent with our earlier results for the two PBOC announcements. In Column 2, we add sector fixed effects: the coefficient on (China's processing imports)* (Exports to China) is now larger and differs significantly from zero at the one per cent confidence level. Similarly, the coefficient on (China's processing exports)*(Imports from China) is negative and significantly different from zero at the 10 per cent level. (China's processing exports)*(Third-market competition) is positive but insignificant, and (Dependence on external finance for investment*Financial openness) is negative and insignificant.

On balance, this analysis of market-perceived policy changes confirms our earlier findings for the two actual PBOC announcements.

\section{Conclusions}

We have analyzed the impact of prospective appreciation of the renminbi exchange rate on the rest of the world using firm-level data. Using movements in stock prices of some 6,000 manufacturing firms in 44 economies, we examine the response of share prices to two announcements of changes in China's currency policy in 2005 and 2010 which plausibly created expectations of faster renminbi appreciation. We then consider four instances of marketperceived changes in exchange rate policy, as reflected in unusually large renminbi movements on the NDF market, each of which was associated with political as opposed to economic factors.

Expectations of renminbi appreciation appear to impact foreign firm valuations both through a general market-sentiment effect, which plausibly reflects diminished fears of trade

\footnotetext{
${ }^{31}$ We cluster standard errors at the level of sector as before.
} 
sanctions and retaliation, and a set of trade-related channels. Renminbi-appreciation expectations positively impact firms selling final goods to China; in contrast, such expectations do not positively affect the share prices of firms selling inputs to China for use in its processing trade; for such firms the effect is if anything negative. There is some evidence that renminbi appreciation positively affects firms competing with China in home and third markets, but the effect in home market is weaker for firms in sectors where China's exports have large importedinput content. Finally, there is evidence of a negative impact on financially-dependent firms which may find it more costly to fund their operations as a result of the upward pressure on yields resulting from reduced Chinese purchases of foreign treasury bonds.

These patterns remain when we control for firm-specific characteristics and sector, year and country fixed effects. They are still evident when we control for local currency movements associated with renminbi appreciation. They continue to hold when abnormal rather than total stock returns are used as the dependent variable. Finally, placebo tests for similar effects on adjoining days do not find them, suggesting that these stock-price responses are not being caused by other events affecting market valuations.

Overall, the message is that across-the-board inferences are misleading. The impact of renminbi appreciation, actual and prospective, on firms, sectors and countries will be very different depending on their circumstances and the specific nature of their interaction with China. 


\begin{tabular}{|c|c|c|c|}
\hline Country & \# of Firms & Country & \# of Firms \\
\hline Argentina & 17 & Japan & 1,159 \\
\hline Australia & 101 & South Korea & 538 \\
\hline Austria & 30 & Malaysia & 228 \\
\hline Belgium & 34 & Mexico & 20 \\
\hline Brazil & 39 & Netherlands & 36 \\
\hline Canada & 199 & New Zealand & 8 \\
\hline Chile & 17 & Norway & 27 \\
\hline Colombia & 6 & Pakistan & 40 \\
\hline Czech Republic & 4 & Peru & 11 \\
\hline Denmark & 35 & Philippines & 8 \\
\hline Egypt & 21 & Poland & 56 \\
\hline Finland & 50 & Portugal & 11 \\
\hline France & 163 & Russian Federation & 19 \\
\hline Germany & 207 & Singapore & 117 \\
\hline Greece & 77 & South Africa & 32 \\
\hline Hong Kong, SAR & 142 & Spain & 34 \\
\hline Hungary & 8 & Sweden & 74 \\
\hline India & 529 & Switzerland & 82 \\
\hline Indonesia & 47 & Thailand & 118 \\
\hline Ireland & 10 & Turkey & 79 \\
\hline Israel & 35 & United Kingdom & 194 \\
\hline Italy & 87 & United States & 1,304 \\
\hline \multicolumn{4}{|c|}{$\begin{array}{l}\text { Note: These are listed manufacturing firms in } 44 \text { economies on July 21, } 2005 \\
\text { and June 21, } 2010 .\end{array}$} \\
\hline
\end{tabular}




\begin{tabular}{|c|c|c|c|c|}
\hline Country & $\begin{array}{l}\text { Market return } \\
(\%, 7 / 21 / 2005)\end{array}$ & $\begin{array}{l}\text { Currency appreciation } \\
(\%, 7 / 21 / 2005)\end{array}$ & $\begin{array}{l}\text { Market return } \\
(\%, 6 / 21 / 2010)\end{array}$ & $\begin{array}{l}\text { Currency appreciation } \\
(\%, 6 / 21 / 2010)\end{array}$ \\
\hline Argentina & -0.53 & 0.03 & 0.40 & 0.06 \\
\hline Australia & 0.64 & 1.16 & 1.31 & 0.40 \\
\hline Austria & -0.57 & 0.10 & 0.85 & -0.64 \\
\hline Belgium & 0.61 & 0.10 & 0.79 & -0.64 \\
\hline Brazil & 1.10 & 0.50 & 0.81 & 0.55 \\
\hline Canada & -0.15 & 0.33 & 0.13 & -0.29 \\
\hline Chile & 0.43 & -0.31 & -0.15 & -0.45 \\
\hline China & 0.86 & 1.98 & 3.62 & 0.44 \\
\hline Colombia & 1.75 & 0.83 & -0.45 & -0.20 \\
\hline Czech Republic & -0.40 & 0.04 & 1.05 & -0.71 \\
\hline Denmark & -0.05 & 0.09 & 0.97 & -0.68 \\
\hline Egypt & -0.38 & -0.02 & 2.35 & 0.11 \\
\hline Finland & -5.78 & 0.10 & 0.22 & -0.64 \\
\hline France & 0.09 & 0.10 & 1.25 & -0.64 \\
\hline Germany & 0.83 & 0.10 & 1.27 & -0.64 \\
\hline Greece & 0.54 & 0.10 & 3.39 & -0.64 \\
\hline Hong Kong SAR & 1.26 & 0.14 & 2.59 & 0.16 \\
\hline Hungary & -0.28 & 0.08 & 3.12 & -0.66 \\
\hline India & 1.46 & 0.97 & 1.77 & 0.79 \\
\hline Indonesia & 1.89 & 0.50 & 0.39 & 0.84 \\
\hline Ireland & 0.94 & 0.10 & 0.27 & -0.64 \\
\hline Israel & 0.00 & 0.76 & 0.92 & 0.00 \\
\hline Italy & 0.02 & 0.10 & 0.27 & -0.64 \\
\hline Japan & -0.64 & 2.22 & 2.07 & -0.34 \\
\hline Korea (South) & -0.55 & 0.82 & 1.64 & 2.48 \\
\hline Malaysia & 1.86 & 0.00 & 1.23 & 2.03 \\
\hline Mexico & -0.50 & 0.11 & 0.14 & 0.09 \\
\hline Netherlands & 0.06 & 0.10 & 1.16 & -0.64 \\
\hline New Zealand & 0.38 & 1.08 & 1.32 & 0.03 \\
\hline Norway & 0.21 & 0.32 & 1.67 & -1.03 \\
\hline Pakistan & -0.48 & 0.05 & 0.52 & 0.04 \\
\hline Peru & 0.27 & 0.00 & 1.07 & -0.67 \\
\hline Philippines & -0.66 & 0.09 & 0.82 & 0.67 \\
\hline Poland & -0.96 & 0.56 & 1.39 & -1.03 \\
\hline Portugal & 0.20 & 0.10 & 0.73 & -0.64 \\
\hline Russian Federation & -0.64 & 0.35 & 2.66 & 0.40 \\
\hline Singapore & 0.48 & 2.12 & 1.77 & 0.58 \\
\hline South Africa & -0.25 & 0.36 & 0.44 & -0.07 \\
\hline Spain & 0.22 & 0.10 & 0.87 & -0.64 \\
\hline Sweden & 1.29 & 0.26 & 0.53 & -0.39 \\
\hline Switzerland & -0.26 & -0.04 & 1.10 & -0.36 \\
\hline Thailand & 0.00 & 2.09 & 2.41 & 0.37 \\
\hline Turkey & 0.95 & 0.47 & 0.56 & -0.18 \\
\hline United Kingdom & 0.12 & 0.70 & 0.90 & -0.53 \\
\hline United States & -0.69 & 0.00 & -0.39 & 0.00 \\
\hline
\end{tabular}




\begin{tabular}{|c|c|c|c|c|c|c|c|c|}
\hline \multicolumn{9}{|c|}{ Table III. Summary statistics } \\
\hline Variables & Obs & Mean & St Dev & Median & $\mathrm{p} 25$ & $\mathrm{p} 75$ & Min & Max \\
\hline \multicolumn{9}{|l|}{ Firm-year level } \\
\hline Stock Return & 12432 & 0.27 & 3.02 & 0.00 & -0.77 & 1.27 & -25.48 & 30.98 \\
\hline Firm size & 12432 & 12.24 & 2.08 & 12.15 & 10.97 & 13.51 & 6.25 & 17.32 \\
\hline \multicolumn{9}{|l|}{ Country-sector-year level } \\
\hline Exports to China & 5211 & 0.05 & 0.10 & 0.01 & 0.00 & 0.06 & 0.00 & 0.44 \\
\hline Imports from China & 5211 & 0.12 & 0.18 & 0.04 & 0.00 & 0.17 & 0.00 & 0.83 \\
\hline Third-market competition & 5211 & 0.07 & 0.09 & 0.04 & 0.01 & 0.10 & 0.00 & 0.50 \\
\hline \multicolumn{9}{|l|}{ US SIC 3-digit sector level } \\
\hline China's Processing Imports & 100 & 0.43 & 0.26 & 0.48 & 0.16 & 0.63 & 0.02 & 0.85 \\
\hline China's Processing Exports & 99 & 0.37 & 0.25 & 0.40 & 0.20 & 0.51 & 0.00 & 0.99 \\
\hline Dependence on External finance & 87 & -0.04 & 0.62 & -0.12 & -0.25 & 0.07 & -1.62 & 4.65 \\
\hline \multicolumn{9}{|c|}{$\begin{array}{l}\text { Note: The sample is for listed manufacturing firms in } 44 \text { countries on July } 21,2005 \text { and June } 21,2010 \text {. Stock return is the log difference in the } \\
\text { closing stock price over the period t- } 1 \text { and } \mathrm{t} \text {, where } \mathrm{t} \text { is the PBOC announcement date. Firm size is the log of assets in US dollars. Exports to } \\
\text { China is measured as exports to China by sector j of country k divided by global exports of sector j of country k. Imports from China is measured } \\
\text { as imports from China by sector } \mathrm{j} \text { in country k divided by total imports of sector } \mathrm{j} \text { in country k. To construct Third-market Competition, we } \\
\text { multiply a third-market's importance to sector j of country k and the share of China's product in the third-market, and then sum the result over } \\
\text { all third markets. To calculate China's Processing Imports for sector } j \text {, we sum over the share of intermediates imports for processing exports } \\
\text { and the share of capital goods imports for processing exports, following Koopman et al. (2008). China's Processing Exports is the percentage of } \\
\text { direct foreign value-added in China's exports, by industry. Dependence on External Finance is industry's intrinsic dependence on external } \\
\text { finance for investment based on Rajan and Zingales (1998). }\end{array}$} \\
\hline
\end{tabular}


Table IV. Impact of PBOC announcements on stock returns: exports to China

\begin{tabular}{|c|c|c|c|c|c|c|c|c|}
\hline & (1) & (2) & (3) & (4) & (5) & (6) & (7) & (8) \\
\hline \multirow[t]{2}{*}{ Exports to China } & $0.41 *$ & $1.32 * * *$ & $1.32 * * *$ & 0.29 & -0.22 & $-1.89 * * *$ & $-2.10 * * *$ & $-2.54 * * *$ \\
\hline & [0.23] & {$[0.27]$} & {$[0.26]$} & {$[0.53]$} & {$[0.43]$} & {$[0.66]$} & [0.58] & {$[0.53]$} \\
\hline \multirow[t]{2}{*}{ China's processing imports*Exports to China } & & $-1.98 * * *$ & $-2.17^{* * *}$ & $-1.57^{* *}$ & $-2.37 * * *$ & $-1.91 * * *$ & & \\
\hline & & {$[0.64]$} & {$[0.62]$} & {$[0.72]$} & {$[0.65]$} & {$[0.73]$} & & \\
\hline \multirow[t]{2}{*}{ China's processing imports } & & -0.031 & 0.074 & & 0.076 & & & \\
\hline & & {$[0.30]$} & {$[0.28]$} & & {$[0.27]$} & & & \\
\hline \multirow[t]{2}{*}{ Firm-Size } & & & $0.100 * * * c$ & $0.064^{* * *}$ & $0.081^{* * *}$ & $0.068 * * *$ & $0.068 * * *$ & $0.068 * * *$ \\
\hline & & & {$[0.020]$} & {$[0.017]$} & [0.022] & [0.017] & [0.017] & [0.017] \\
\hline \multirow[t]{2}{*}{ RMB appreciation*Exports to China } & & & & & $3.94 * * *$ & $4.43 * * *$ & $4.37^{* * *}$ & $4.34 * * *$ \\
\hline & & & & & {$[0.77]$} & {$[0.67]$} & {$[0.66]$} & {$[0.66]$} \\
\hline \multirow[t]{2}{*}{ Local currency appreciation*Exports to China } & & & & & $-1.29 * * *$ & -0.32 & -0.35 & -0.35 \\
\hline & & & & & {$[0.24]$} & {$[0.27]$} & {$[0.26]$} & {$[0.26]$} \\
\hline \multirow[t]{2}{*}{ RMB appreciation } & & & & & $0.77^{* * *}$ & & & \\
\hline & & & & & {$[0.26]$} & & & \\
\hline \multirow[t]{2}{*}{ Local currency appreciation } & & & & & $0.14^{* * *}$ & $-0.25 * * *$ & $-0.25 * * *$ & $-0.25 * * *$ \\
\hline & & & & & [0.045] & {$[0.074]$} & {$[0.074]$} & {$[0.074]$} \\
\hline \multirow[t]{2}{*}{ High China's processing imports* Exports to China } & & & & & & & $-1.01 * * *$ & \\
\hline & & & & & & & [0.32] & \\
\hline \multirow[t]{2}{*}{ Component sector*Exports to China } & & & & & & & & $-0.67 * * *$ \\
\hline & & & & & & & & {$[0.24]$} \\
\hline \multirow[t]{2}{*}{ Constant } & $0.23 * * *$ & 0.25 & $-1.00 * * *$ & & $-1.36 * * *$ & & & \\
\hline & {$[0.072]$} & {$[0.15]$} & {$[0.32]$} & & {$[0.30]$} & & & \\
\hline Country fixed effects & $\mathrm{N}$ & $N$ & $\mathrm{~N}$ & $Y$ & $\mathrm{~N}$ & Y & Y & Y \\
\hline Year fixed effects & N & $\mathrm{N}$ & $\mathrm{N}$ & Y & $\mathrm{N}$ & Y & Y & Y \\
\hline Sector fixed effects & $\mathrm{N}$ & $N$ & $\mathrm{~N}$ & Y & $\mathrm{N}$ & Y & Y & $\mathrm{Y}$ \\
\hline Observations & 12,432 & 12,432 & 12,432 & 12,432 & 12,432 & 12,432 & 12,432 & 12,432 \\
\hline R-squared & 0.000 & 0.001 & 0.006 & 0.065 & 0.024 & 0.072 & 0.072 & 0.072 \\
\hline
\end{tabular}

Note: The sample is for listed manufacturing firms in 44 countries on July 21, 2005 and June 21, 2010. Stock return is the log difference in the closing price over the period t-1 and t, where $\mathrm{t}$ is the PBOC announcement date. Firm size is the log of assets in US dollars. Exports to China is measured as exports to China by sector $\mathrm{j}$ of country $\mathrm{k}$ divided by global exports of sector $\mathrm{j}$ of country k. To calculate China's Processing Imports for sector $j$, we sum over the share of intermediates imports for processing exports and the share of capital goods imports for processing exports, following Koopman et al (2008). Local currency appreciation is the log difference in the closing Dollar/Local-currency rate from t-1 to t. High China's processing imports is a dummy for whether a sector has an above-median value for China's Processing Imports. Component sector dummy is defined as U.S. SIC Industry Group 367 (Electronic Components and Accessories). Standard errors are clustered at the level of 3-digit US SIC sector. Robust standard errors in brackets; ${ }^{* * *} \mathrm{p}<0.01, * * \mathrm{p}<0.05, * \mathrm{p}<0.1$. 
Table V. Impact of PBOC announcements on stock returns: imports from China

\begin{tabular}{|c|c|c|c|c|c|}
\hline & (1) & (2) & (3) & (4) & (5) \\
\hline \multirow[t]{2}{*}{ Imports from China } & $0.49 *$ & $1.58 * * *$ & $1.59 * * *$ & $0.69 *$ & -0.79 \\
\hline & [0.28] & {$[0.48]$} & {$[0.46]$} & {$[0.35]$} & {$[0.66]$} \\
\hline \multirow{2}{*}{ China's processing exports*Imports from China } & & $-1.59 * *$ & $-1.67 * *$ & -0.72 & $-0.85^{*}$ \\
\hline & & {$[0.75]$} & {$[0.73]$} & {$[0.48]$} & {$[0.50]$} \\
\hline \multirow[t]{2}{*}{ China's processing exports } & & -0.29 & -0.20 & & \\
\hline & & {$[0.26]$} & {$[0.26]$} & & \\
\hline \multirow[t]{2}{*}{ Firm-Size } & & & $0.094 * * *$ & $0.062 * * *$ & $0.066 * * *$ \\
\hline & & & {$[0.020]$} & {$[0.017]$} & [0.018] \\
\hline \multirow[t]{2}{*}{ RMB appreciation*Imports from China } & & & & & $2.28 * * *$ \\
\hline & & & & & {$[0.72]$} \\
\hline \multirow[t]{2}{*}{ Local currency appreciation*Imports from China } & & & & & -0.18 \\
\hline & & & & & {$[0.15]$} \\
\hline \multirow[t]{2}{*}{ Local currency appreciation } & & & & & $-0.24 * * *$ \\
\hline & & & & & [0.067] \\
\hline \multirow[t]{2}{*}{ Constant } & $0.20 * *$ & $0.28 *$ & $-0.90 * * *$ & & \\
\hline & [0.079] & {$[0.14]$} & [0.32] & & \\
\hline Country fixed effects & $\mathrm{N}$ & $\mathrm{N}$ & $\mathrm{N}$ & $\mathrm{Y}$ & Y \\
\hline Year fixed effects & $\mathrm{N}$ & $\mathrm{N}$ & $\mathrm{N}$ & $\mathrm{Y}$ & Y \\
\hline Sector fixed effects & $\mathrm{N}$ & $\mathrm{N}$ & $\mathrm{N}$ & Y & Y \\
\hline Observations & 12,432 & 12,318 & 12,318 & 12,318 & 12,318 \\
\hline R-squared & 0.001 & 0.005 & 0.010 & 0.065 & 0.072 \\
\hline
\end{tabular}

Note: The sample is for listed manufacturing firms in 44 countries on July 21, 2005 and June 21, 2010. Stock return is the log difference in the closing price over the period $\mathrm{t}-1$ and $\mathrm{t}$, where $\mathrm{t}$ is the PBOC announcement date. Firm size is the log of assets in US dollars. Imports from China is measured as imports from China by sector $\mathrm{j}$ in country k divided by total imports of sector $\mathrm{j}$ in country $\mathrm{k}$. China's Processing Exports is the percentage of direct foreign value-added in China's exports, by industry, following Koopman et al (2008). Local currency appreciation is the log difference in the closing Dollar/Local-currency rate from t- 1 to t. Standard errors are clustered at the level of 3-digit US SIC sector. Robust standard errors in brackets; ${ }^{* * *} p<0.01,{ }^{* *} p<0.05,{ }^{*} p<0.1$. 


\section{Table VI. Impact of PBOC announcements on stock returns: Controlling for third-market competition}

$1.52 * * *$

Third-market competition

China's processing exports*Third-market competition

China's processing exports

Firm-Size

Local currency appreciation*Third-market competition

RMB appreciation*Third-market competition

Local currency appreciation

Constant

Country fixed effects

Year fixed effects

Sector fixed effects

Observations

R-squared

\section{(1)}

(2)

[0.56]

(2)

\section{(3)}

(4)

$2.41 * * \quad-0.40$

$-4.64 * * *$

[1.10]

[0.78]

[1.56]

$-0.89$

1.61

0.82

[1.84]

[1.39]

[1.37]

$-0.47$

[0.29]

$0.062^{* * *} \quad 0.065^{* * *}$

[0.017] [0.018]

0.57

[0.36]

$5.33 * * *$

[1.91]

$-0.34 * * *$

[0.069]

$0.16 * * \quad 0.33 * *$

[0.081]

[0.16]
$\mathrm{N} \quad \mathrm{N}$

$\mathrm{N} \quad \mathrm{N}$

$\mathrm{N} \quad \mathrm{N}$

$\mathrm{N}$

$\begin{array}{ll}Y & Y \\ Y & Y \\ Y & Y\end{array}$

$12,432 \quad 12,318 \quad 12,318 \quad 12,318$

Note: The sample is for listed manufacturing firms in 44 countries on July 21, 2005 and June 21, 2010. Stock return is the log difference in the closing price over the period $\mathrm{t}-1$ and $\mathrm{t}$, where $\mathrm{t}$ is the PBOC announcement date. Firm size is the log of assets in US dollars. To construct Third-market Competition, we multiply a third-market's importance to sector $\mathrm{j}$ of country $\mathrm{k}$ and the share of China's product in the third-market, and then sum the result over all third markets. China's Processing Exports is the percentage of direct foreign value-added in China's exports, by industry, following Koopman et al (2008). Local currency appreciation is the log difference in the closing Dollar/Local-currency rate from t- 1 to $t$. Standard errors are clustered at the level of 3-digit US SIC sector. Robust standard errors in brackets; ${ }^{* * *} p<0.01, * * p<0.05, * p<0.1$. 
Table VII. Impact of PBOC announcements on stock returns:

Controlling for financial channel

\begin{tabular}{|c|c|c|c|c|c|}
\hline & (1) & (2) & (3) & (4) & (5) \\
\hline Dependence on external finance for investment & $\begin{array}{c}-0.15^{* * *} \\
{[0.017]}\end{array}$ & $\begin{array}{l}-0.13 * * * \\
{[0.014]}\end{array}$ & $\begin{array}{c}-0.082 * * * \\
{[0.012]}\end{array}$ & $\begin{array}{c}-0.047 * * * \\
{[0.015]}\end{array}$ & \\
\hline Firm-Size & & $\begin{array}{c}0.090 * * * \\
{[0.017]}\end{array}$ & $\begin{array}{c}0.062^{* * *} \\
{[0.018]}\end{array}$ & $\begin{array}{c}0.061 * * * \\
{[0.018]}\end{array}$ & $\begin{array}{c}0.061 * * * \\
{[0.017]}\end{array}$ \\
\hline $\begin{array}{l}\text { Dependence on external finance for investment } \\
*_{\text {financial openness }}\end{array}$ & & & & $\begin{array}{c}-0.010 * * * \\
{[0.0024]}\end{array}$ & $\begin{array}{c}-0.010 * * * \\
{[0.0027]}\end{array}$ \\
\hline Financial openness & & & & $\begin{array}{c}0.034 \\
{[0.042]}\end{array}$ & $\begin{array}{c}0.035 \\
{[0.042]}\end{array}$ \\
\hline Constant & $\begin{array}{c}0.32 * * * \\
{[0.053]}\end{array}$ & $\begin{array}{c}-0.80 * * * \\
{[0.21]}\end{array}$ & & & \\
\hline Country fixed effects & $\mathrm{N}$ & $\mathrm{N}$ & Y & Y & Y \\
\hline Year fixed effects & $\mathrm{N}$ & $\mathrm{N}$ & Y & $\mathrm{Y}$ & $\mathrm{Y}$ \\
\hline Sector fixed effects & $\mathrm{N}$ & $\mathrm{N}$ & $\mathrm{N}$ & $\mathrm{N}$ & $\mathrm{Y}$ \\
\hline Observations & 12,005 & 12,005 & 12,005 & 12,005 & 12,005 \\
\hline R-squared & 0.004 & 0.009 & 0.055 & 0.056 & 0.066 \\
\hline \multicolumn{6}{|c|}{$\begin{array}{l}\text { Note: The sample is for listed manufacturing firms in } 44 \text { countries on July } 21,2005 \text { and June } 21,2010 \text {. Stock return is the log } \\
\text { difference in the closing price over the period t- } 1 \text { and t, where } t \text { is the PBOC announcement date. Firm size is the log of assets in } \\
\text { US dollars. Dependence on External Finance is industry's intrinsic dependence on external finance for investment based on Rajan } \\
\text { and Zingales (1998). Financial openness is measured as the country's foreign assets and liabilities over GDP, following Lane and } \\
\text { Milesi-Ferretti }(2007) \text {. Standard errors are clustered at the level of 3-digit US SIC sector. Robust standard errors in brackets; }{ }^{* * *} \\
\text { p<0.01, }{ }^{* *} p<0.05, * p<0.1 \text {. }\end{array}$} \\
\hline
\end{tabular}


Table VIII. Impact of PBOC announcements on stock returns: --Combining trade and financial channels

\begin{tabular}{|c|c|c|}
\hline & (1) & $(2)$ \\
\hline \multirow[t]{2}{*}{ Exports to China } & 0.28 & 0.42 \\
\hline & {$[0.40]$} & [0.38] \\
\hline \multirow[t]{2}{*}{ China's processing imports*Exports to China } & $-1.82 * *$ & $-1.92 * * *$ \\
\hline & {$[0.80]$} & {$[0.68]$} \\
\hline \multirow[t]{2}{*}{ China's processing imports } & 0.14 & \\
\hline & {$[0.16]$} & \\
\hline \multirow[t]{2}{*}{ Imports from China } & $1.18^{* * *}$ & $1.02 * *$ \\
\hline & {$[0.40]$} & {$[0.40]$} \\
\hline \multirow[t]{2}{*}{ China's processing exports*Imports from China } & $-1.90 * *$ & $-1.33^{* *}$ \\
\hline & {$[0.74]$} & {$[0.68]$} \\
\hline \multirow[t]{2}{*}{ Third-market competition } & -1.19 & $-1.87^{* *}$ \\
\hline & [0.85] & {$[0.94]$} \\
\hline \multirow[t]{2}{*}{ China's processing exports ${ }^{*}$ Third-market competition } & 1.89 & $3.68 * *$ \\
\hline & {$[1.71]$} & [1.87] \\
\hline \multirow[t]{2}{*}{ China's processing exports } & -0.068 & \\
\hline & {$[0.17]$} & \\
\hline \multirow[t]{2}{*}{ Dependence on external finance for investment } & $-0.043 * * *$ & \\
\hline & [0.015] & \\
\hline \multirow{2}{*}{$\begin{array}{l}\text { Dependence on external finance for investment } \\
\text { *financial openness }\end{array}$} & $-0.010 * * *$ & $-0.011 * * *$ \\
\hline & {$[0.0027]$} & {$[0.0026]$} \\
\hline \multirow[t]{2}{*}{ Financial openness } & $0.056 * * *$ & $0.051 * * *$ \\
\hline & [0.016] & [0.017] \\
\hline \multirow[t]{2}{*}{ Firm-Size } & $0.067 * * *$ & $0.070 * * *$ \\
\hline & [0.019] & {$[0.018]$} \\
\hline Country-year fixed effects & $\mathrm{Y}$ & $\mathrm{Y}$ \\
\hline Sector fixed effects & $\mathrm{N}$ & $\mathrm{Y}$ \\
\hline Observations & 11,891 & 11,891 \\
\hline R-squared & 0.082 & 0.091 \\
\hline
\end{tabular}

Note: The sample is for listed manufacturing firms in 44 countries on July 21, 2005 and June 21, 2010. Stock return is the log difference in the closing price over the period t-1 and t, where $t$ is the PBOC announcement date. Other variables are defined in Table III. Standard errors are clustered at the level of 3-digit US SIC sector. Robust standard errors in brackets; *** $p<0.01,{ }^{* *} p<0.05, * p<0.1$. 


\section{Table IX. Impact of PBOC announcements on abnormal stock returns: exporting to China}

(1)

$\begin{array}{cccc}-0.59 * * * & 0.20 & 0.21 & 0.58 \\ {[0.20]} & {[0.35]} & {[0.49]} & {[0.76]} \\ & -1.93 * * & -2.01 * * * & -1.78 * * * \\ & {[0.78]} & {[0.69]} & {[0.67]} \\ & 0.20 & & \end{array}$

China's processing imports

[0.15]

Firm-Size

$0.049 * * * \quad 0.049 * * *$

[0.016] [0.016]

RMB appreciation*Exports to China

$-0.27$

[0.69]

Local currency appreciation*Exports to China

$-0.43^{*}$

0.076

[0.076]

Constant

$-0.045$

[0.040]

Country fixed effects

Year fixed effects

Sector fixed effects

Observations

$\mathrm{N}$

$\mathrm{N}$

$\mathrm{N}$

12,350

0.001

$\mathrm{N}$
$\mathrm{N}$
$\mathrm{N}$

Y

$Y$

$Y$

12,350

12,350

0.026

0.001
$-0.12 *$

[0.064]

Note: The sample is for listed manufacturing firms in 44 countries on July 21, 2005 and June 21, 2010. Dependent variable is the abnormal stock return estimated using a market model over the period $\mathrm{t}-1$ and $\mathrm{t}$, where $\mathrm{t}$ is the PBOC announcement date. Firm size is the log of assets in US dollars. Exports to China is measured as exports to China by sector $\mathrm{j}$ of country $\mathrm{k}$ divided by global exports of sector $\mathrm{j}$ of country k. To calculate China's Processing Imports for sector $j$, we sum over the share of intermediates imports for processing exports and the share of capital goods imports for processing exports, following Koopman et al (2008). Local currency appreciation is the log difference in the closing Dollar/Local-currency rate from t-1 to t. Standard errors are clustered at the level of 3-digit US SIC sector. Robust standard errors in brackets; *** $p<0.01,{ }^{* *} p<0.05, * p<0.1$. 


\section{Table X. Impact of PBOC announcements on abnormal stock returns:}

Importing from China

\begin{tabular}{|c|c|c|c|c|}
\hline & $(1)$ & $(2)$ & (3) & $(4)$ \\
\hline \multirow[t]{2}{*}{ Imports from China } & -0.12 & $1.26 * * *$ & $0.93 * *$ & 0.67 \\
\hline & {$[0.24]$} & {$[0.35]$} & {$[0.38]$} & {$[0.85]$} \\
\hline \multirow[t]{2}{*}{ China's processing exports *Imports from China } & & $-2.58 * * *$ & $-1.74 * * *$ & $-1.88 * * *$ \\
\hline & & {$[0.55]$} & {$[0.54]$} & {$[0.56]$} \\
\hline \multirow[t]{2}{*}{ China's processing exports } & & $0.35^{*}$ & & \\
\hline & & {$[0.20]$} & & \\
\hline \multirow[t]{2}{*}{ Firm-Size } & & $0.065^{* *}$ & $0.063 * *$ & $0.063 * *$ \\
\hline & & [0.026] & {$[0.026]$} & [0.026] \\
\hline \multirow[t]{2}{*}{ RMB appreciation*Imports from China } & & & & 0.75 \\
\hline & & & & {$[0.88]$} \\
\hline \multirow[t]{2}{*}{ Local currency appreciation*Imports from China } & & & & $-0.32 *$ \\
\hline & & & & {$[0.17]$} \\
\hline \multirow[t]{2}{*}{ Local currency appreciation } & & & & 0.066 \\
\hline & & & & {$[0.080]$} \\
\hline \multirow[t]{2}{*}{ Constant } & -0.029 & $-0.99 * *$ & & \\
\hline & {$[0.064]$} & {$[0.39]$} & & \\
\hline Country fixed effects & $\mathrm{N}$ & $\mathrm{N}$ & $Y$ & Y \\
\hline Year fixed effects & $\mathrm{N}$ & $\mathrm{N}$ & $Y$ & $Y$ \\
\hline Sector fixed effects & $\mathrm{N}$ & $\mathrm{N}$ & $Y$ & $\mathrm{Y}$ \\
\hline Observations & 9,939 & 9,839 & 9,839 & 9,839 \\
\hline R-squared & 0.000 & 0.005 & 0.031 & 0.032 \\
\hline \multicolumn{5}{|c|}{$\begin{array}{l}\text { Note: The sample is for listed manufacturing firms in } 44 \text { countries on July } 21,2005 \text { and June } 21,2010 . \\
\text { Dependent variable is the abnormal stock return estimated using a market model over the period t- } 1 \text { and t, } \\
\text { where } t \text { is the PBOC announcement date. Firm size is the log of assets in US dollars. Imports from China is } \\
\text { measured as imports from China by sector } \mathrm{j} \text { in country k divided by total imports of sector } \mathrm{j} \text { in country k. } \\
\text { China's Processing Exports is the percentage of direct foreign value-added in China's exports, by industry, } \\
\text { following Koopman et al (2008). Local currency appreciation is the log difference in the closing Dollar/Local- } \\
\text { currency rate from t- } 1 \text { to t. Standard errors are clustered at the level of 3-digit US SIC sector. Robust } \\
\text { standard errors in brackets; }{ }^{* * *} p<0.01,{ }^{* *} p<0.05,{ }^{*} p<0.1 \text {. }\end{array}$} \\
\hline
\end{tabular}


Table XI. Impact of PBOC announcements on abnormal stock returns: --Combining trade and financial channels

\begin{tabular}{|c|c|c|}
\hline & $(1)$ & $(2)$ \\
\hline \multirow[t]{2}{*}{ Exports to China } & 0.30 & 0.51 \\
\hline & {$[0.42]$} & {$[0.39]$} \\
\hline \multirow[t]{2}{*}{ China's processing imports*Exports to China } & $-1.88 * *$ & $-2.15 * * *$ \\
\hline & {$[0.85]$} & {$[0.73]$} \\
\hline \multirow[t]{2}{*}{ China's processing imports } & 0.20 & \\
\hline & {$[0.14]$} & \\
\hline \multirow[t]{2}{*}{ Imports from China } & $1.15^{* * *}$ & $0.95^{* * *}$ \\
\hline & {$[0.34]$} & {$[0.36]$} \\
\hline \multirow[t]{2}{*}{ China's processing exports*Imports from China } & $-2.07 * * *$ & $-1.56 * *$ \\
\hline & {$[0.70]$} & {$[0.64]$} \\
\hline \multirow[t]{2}{*}{ Third-market competition } & -1.05 & -1.49 \\
\hline & {$[0.82]$} & {$[0.91]$} \\
\hline \multirow[t]{2}{*}{ China's processing exports*Third-market competition } & 1.67 & 2.74 \\
\hline & {$[1.72]$} & [1.93] \\
\hline \multirow[t]{2}{*}{ China's processing exports } & -0.021 & \\
\hline & {$[0.15]$} & \\
\hline \multirow[t]{2}{*}{ Dependence on external finance for investment } & -0.019 & \\
\hline & [0.016] & \\
\hline \multirow{2}{*}{$\begin{array}{l}\text { Dependence on external finance for investment } \\
\quad *_{\text {financial openness }}\end{array}$} & $-0.010 * * *$ & $-0.011 * * *$ \\
\hline & {$[0.0029]$} & {$[0.0026]$} \\
\hline \multirow[t]{2}{*}{ Financial openness } & $-0.028 * *$ & $-0.037^{* * *}$ \\
\hline & [0.014] & {$[0.014]$} \\
\hline \multirow[t]{2}{*}{ Firm-Size } & $0.041 * *$ & $0.048 * * *$ \\
\hline & [0.018] & {$[0.017]$} \\
\hline Country-year fixed effects & Y & Y \\
\hline Sector fixed effects & $\mathrm{N}$ & Y \\
\hline Observations & 11,815 & 11,815 \\
\hline R-squared & 0.030 & 0.039 \\
\hline \multicolumn{3}{|c|}{$\begin{array}{l}\text { Note: The sample is for listed manufacturing firms in } 44 \text { countries on July } 21,2005 \text { and June } 21,2010 \text {. } \\
\text { Dependent variable is the abnormal stock return estimated using a market model over the period t- } 1 \\
\text { and } t \text {, where } t \text { is the PBOC announcement date. Other variables are defined in Table III. Standard errors } \\
\text { are clustered at the level of 3-digit US SIC sector. Robust standard errors in brackets; }{ }^{* * *} p<0.01 \text {, }^{* *} \\
p<0.05,{ }^{*} p<0.1 \text {. }\end{array}$} \\
\hline
\end{tabular}




\section{Table XII. Impact of Market-Perceived Policy Changes on Stock Returns}

(1)

(2)

Exports to China

$1.43^{* * *}$

[0.45]

$1.66^{* * *}$

China's processing imports*Exports to China

$-2.07^{* *}$

[0.48]

[0.81]

China's processing imports

$-0.22 *$

[0.12]

Imports from China

$0.48^{*}$

[0.24]

$-0.55$

[0.45]

0.19

[0.13]

Third-market competition

$-0.37$

[0.62]

0.18

[1.61]

$-0.024$

Dependence on external finance for investment

[0.018]

$-0.0043$

[0.0063]

$-0.086$

[0.088]

0.017

[0.017]

$\mathrm{Y}$

$\mathrm{N}$

23,712

0.107

$-0.6$

[0.66]

0.63

[1.80]

[0.88]

$0.70 * * *$

[0.26]

$-0.81 *$

[0.47]

\section{$[1.80]$}

$-0.0089$

[0.0072]

$-0.084$

[0.090]

0.017

[0.018]

Country-year fixed effects

Sector fixed effects

Observations

R-squared

Note: The sample is for listed manufacturing firms in 44 countries for four perceived renminbi policy changes in year 2003 as listed in Appendix Table 1. Stock return is the log difference in the closing price over the period t-1 and t, where $t$ is the event date. Other variables are defined in Table III. Standard errors are clustered at the level of 3-digit US SIC sector. Robust standard errors in brackets; *** $p<0.01, * * p<0.05, * p<0.1$. 


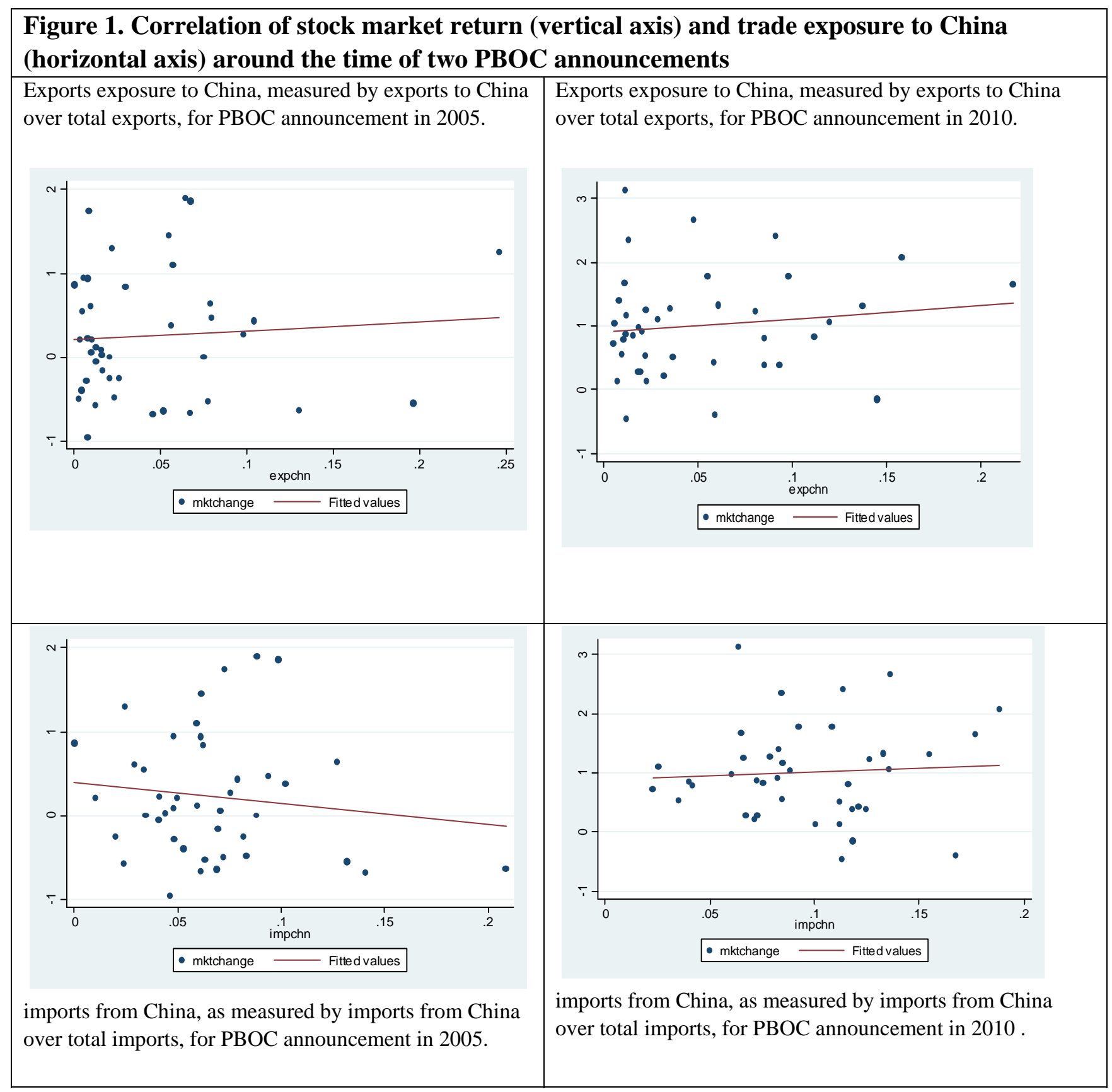




\section{References}

Ahmed, Shaghil, 2009, Are Chinese Exports Sensitive to Changes in the Exchange Rate? International Finance Discussion Paper 987, Board of Governors of the Federal Reserve System.

Bartov, Eli and Gordon Bodnar, 1994, Firm Valuation, Earnings Expectations, and the Exchange Rate Exposure Effect, Journal of Finance 49, 1755- 1785.

Bernanke, Ben S., 2005, The Global Saving Glut and the U.S. Current Account Deficit, www.federalreserve.gov/boarddocs/speeches/2005/200503102/default.htm.

Bernanke, Ben S., Bertaut, Carol, DeMarco, Laurie Pounder and Kamin, Steven, 2011, International Capital Flows and the Returns to Safe Assets in the United States, 2003-2007, International Finance Discussion Paper 1014, Board of Governors of the Federal Reserve System.

Blanchard, Olivier and Gian Maria Milesi-Ferretti, 2011, (Why) Should Current Account Balances Be Reduced? IMF Staff Discussion Note 11/03.

Bartram, Söhnke M., Gregory W. Brown, and Bernadette A. Minton, 2010, Resolving the Exposure Puzzle: The Many Facets of Exchange Rate Exposure, Journal of Financial Economics 95, 148-173.

Bodnar, Gordon , Bernard Dumas and Richard Marston, 2002, Pass-through and Exposure, Journal of Finance 57(1), 199-231.

Cheung, Yin-Wong, Menzie D. Chinn, and Eiji Fujii, 2010, China's Current Account and Exchange Rate, in Robert Feenstra and Shang-Jin Wei, eds.: China's Growing Role in World Trade (University of Chicago Press).

Dominguez, Kathryn and Linda Tesar, 2006, Exchange Rate Exposure, Journal of International Economics 68, 188-218.

Dooley, Michael, David Folkerts-Landau and Peter Garber, 2009, Bretton Woods II Still Defines The International Monetary System, Pacific Economic Review 14, 297-311.

Eichengreen, Barry, 2007, China’s Exchange Rate Regime: The Long and Short of It, in Charles Calomiris, ed.: China's Financial Transition at a Crossroads (Columbia University Press).

Engel, Charles, 2009, Exchange Rate Policies, Federal Reserve Bank of Dallas Staff Paper. 
Evenett, Simon and Joseph Francois, 2010, Will Chinese Revaluation Create American Jobs? VoxEU (April).

Feenstra, Robert and Gordon Hanson, 2005, Ownership and Control in Outsourcing to China: Estimating the Property-Rights Theory of the Firm, Quarterly Journal of Economics 120, 729762.

Forbes, Kristin, 2004, The Asian Flu and the Russian Virus: The International Transmission of Crises in Firm-Level Data, Journal of International Economics 63, 59-92.

Francois, Joseph, 2010, Deconstructing Sino-US Codependence: Revaluation, Tariffs, Exports and Jobs, in Simon Evenett, ed.: The US-Sino Currency Dispute: New Insights from Economics Politics and Law (London, CEPR and VoxEU).

Garcia-Herrero, Alicia and Tuuli Koivu, 2009, China’s Exchange Rate Policy and Asian Trade, Economie Internationale 116, 53-92.

Griffin, John M., 2002, Are the Fama and French Factors Global or Country Specific? Review of Financial Studies 15, 783-803.

Griffin, John M and Stulz, Rene M, 2001, International Competition and Exchange Rate Shocks: A Cross-Country Industry Analysis of Stock Returns, Review of Financial Studies 14, 215-41.

Hanson, Gordon and Raymond Robertson, 2010, China and the Manufacturing Exports of Other Developing Countries, in Robert Feenstra and Shang Jin Wei, eds.: China's Growing Role in World Trade (University of Chicago Press).

He, Jia and Lilian Ng, 1998, The Foreign Exchange Exposure of Japanese Multinational Corporations, Journal of Finance 53, 733-753.

Koopman, Robert, Zhi Wang, and Shang-jin Wei, 2008, How Much of Chinese Exports Is Really Made in China? Assessing Foreign and Domestic Value-Added in Gross Exports, United States International Trade Commission Working Paper No. 2008-03-B.

Koopman, Robert, William Powers, Zhi Wang, Shang-Jin Wei, 2010, Give Credit Where Credit Is Due: Tracing Value Added in Global Production Chains, NBER Working Paper No. 16426.

Lane, Philip and Milesi-Ferretti, Gian Maria, 2007, The External Wealth of Nations Mark II: Revised and Extended Estimates of Foreign Assets and Liabilities, 1970-2004, Journal of International Economics 73, 223-50.

Mackinlay, Craig, 1997, Event Studies in Economics and Finance, Journal of Economic Literature 35, 13-39. 
Marquez, Jaime and John Schindler, 2006, Exchange-Rate Effects on China's Trade: An Interim Report, International Finance Discussion Paper 861, Board of Governors of the Federal Reserve System.

Parsley, David and Helen Popper, 2006, Exchange Rate Pegs and Exchange Rate Exposures in East Asia, Journal of International Money and Finance 25, 992-1009.

Phylaktis, Kate and Fabiola Ravazzolo, 2005, Stock Prices and Exchange Rate Dynamics, Journal of International Money and Finance 24, 1031-1053.

Rajan, Raghuram and Luigi Zingales, 1998, Financial Dependence and Growth, American Economic Review 88, 559-86.

Scott, Robert E., 2010, Unfair China Trade Costs Local Jobs, Economic Policy Institute Policy Brief No. 260.

Tong, Hui and Shang-Jin Wei, 2011, The Composition Matters: Capital Inflows and Liquidity Crunch during a Global Economic Crisis, Review of Financial Studies 24, 2023-52.

Williamson, Rohan, 2001, Exchange Rate Exposure and Competition: Evidence from the World Automotive Industry, Journal of Financial Economics 59, 441- 475. 


\section{Appendix Table 1: Market-perceived changes in China's currency policy}

\begin{tabular}{|c|c|}
\hline Date & 12-month RMB NDF Change (\%; daily) \\
\hline Jan 6, 2003 & $\begin{array}{l}0.75 \\
\text { "Reported remarks by U.S. Undersecretary for International Affairs John Taylor at the } \\
\text { weekend also appeared to support greater flexibility for the yuan exchange rate. Those } \\
\text { weekend comments, in particular, sparked the yuan forward market into life." } \\
\text { Source: “ China Yuan Sees Upward Pressure In Offshore Market", Dow Jones International } \\
\text { News, Janurary 7, } 2003\end{array}$ \\
\hline Sept 22, 2003 & $\begin{array}{l}0.74 \\
\text { "Chinese yuan one-year non-deliverable forwards surged further into record territory on } \\
\text { Monday,..., after the Group of Seven called for flexible currency regimes... The G7 industrial } \\
\text { nations on Saturday called for more exchange rate flexibility to iron out global economic } \\
\text { balances." } \\
\text { Source: "China Yuan NDF Premium Rises to Record 2,520 pts", Reuters News, Sept 22, } 2003 .\end{array}$ \\
\hline Sept 23, 2003 & $\begin{array}{l}1.16 \\
\text { "Speculation of a Chinese yuan revaluation pushed offshore dollar-yuan nondeliverable } \\
\text { forward discounts to new records Tuesday...The NDF market experienced one of its most } \\
\text { volatile sessions after a weekend statement by the Group of Seven leading industrial nations } \\
\text { called for flexible exchange rates." } \\
\text { Source: "China Yuan Ends Higher; NDF Discounts At New Records", Dow Jones International } \\
\text { News, September 23, } 2003 \text {. }\end{array}$ \\
\hline Oct 3, 2003 & $\begin{array}{l}0.96 \\
\text { "The one-year Chinese yuan non-delivery forwards (NDF) jumped to a new one-year highs } \\
\text { after the US Treasury Secretary John Snow told lawmakers that he hopes to see China move } \\
\text { to a more flexible exchange rate." } \\
\text { Source: "News Briefs - The one-year Chinese yuan non-delivery forwards (NDF) jumped to a } \\
\text { new one-year highs", Taiwan Business News, October 4, } 2003 \text {. }\end{array}$ \\
\hline
\end{tabular}

